\title{
Teaching Strategies for Mathematical Problem-Solving through the Lens of Secondary School Teachers
}

\author{
Afiqah Hamizah Noor Ishak ${ }^{1}$, Sharifah Osman ${ }^{1}$, Chiang Kok Wei ${ }^{1}$, \\ Dian Kurniati ${ }^{2}$, Norhafizah Ismail ${ }^{3}$, A. Wilda Indra Nanna ${ }^{4}$ \\ ${ }^{1}$ Universiti Teknologi Malaysia, Johor Bahru, Malaysia \\ ${ }^{2}$ Universitas Jember, Jember, Indonesia \\ ${ }^{3}$ Politeknik Mersing, Johor, Malaysia \\ ${ }^{4}$ Universitas Borneo Tarakan, Tarakan, Indonesia
}

\begin{abstract}
Many studies have been conducted on problem-solving but only a small number of studies emphasized the strategies of teaching problem-solving. This paper explores the teaching strategies for mathematical problem-solving in a secondary school in Johor, Malaysia. It involves a qualitative study in which a semi-structured interview was conducted with mathematics teachers. Data were analyzed using a sixstep thematic analysis. The results can be viewed from three contexts of findings, namely the teaching strategies, the problems faced by teachers, and the solutions to overcome the problems. The findings revealed that there are teachers who have implemented personal teaching strategies, namely the Easy-Maths Model and the Cut-Stop-Solve Model to effectively teach mathematical problem-solving. The findings also explained some problems in teaching mathematical problem-solving, whereby students' weaknesses in basic mathematics emerged as the main drawback. This study provides useful information to teachers on the different strategies for teaching mathematical problem-solving.
\end{abstract}

Keywords - Mathematical Problem-Solving, Teachers' Perspectives, Secondary School, Teaching Strategies, Qualitative Study.

DOI: 10.18421/TEM102-31

https://doi.org/10.18421/TEM102-31

Corresponding author: Sharifah Osman, Universiti Teknologi Malaysia, Johor Bahru, Malaysia. Email: sharifah.o@utm.my

Received: 24 December 2020.

Revised: 30 April 2021.

Accepted: 05 May 2021.

Published: 27 May 2021.

(c) BY.NC-ND (C) 2021 Sharifah Osman et al; published by UIKTEN. This work is licensed under the Creative Commons Attribution-NonCommercial-NoDerivs 4.0 License.

The article is published with Open Access at www.temjournal.com

\section{Introduction}

People may encounter problems and face many challenges that demand solutions. Sometimes, some of their problems are more complex than others. Therefore, people should recognize the importance of problem-solving skills in helping them to cope with daily life problems. The approach that most people use to solve a problem is universal, there is no right or wrong; it depends on the type of problem faced as well as education level. Problem-solving has been a prominent research field in mathematics education [1].

Mathematical problem-solving involves several steps. Some students find it too hard to solve a complex mathematical problem although they know the steps to solve them [2]. Therefore, the teachers' role is crucial in helping students gain a deep understanding of mathematics. Appropriate teaching strategies will help students solve mathematical problems effectively. Besides that, it is important to implement several teaching strategies in mathematics, especially for problem-solving, as students have different learning abilities [3].

In past studies, researchers focused more on students' difficulties in learning mathematics without paying close attention to the teaching strategies to solve these mathematical problems [4], [5]. The issue of solving mathematical questions is not only depending on the students, but also on the teachers. Teachers are also responsible for applying an appropriate strategy to teach their students effectively. It is the teacher who is at fault if he fails to introduce effective strategies to help students learn a subject properly and to facilitate the learning process for students [6]. Moreover, teachers assume that students have problems with the teaching content. The teachers fail to reflect on their strategies to help their students understand what they teach [7].

Nowadays, mathematics education is becoming more important, and more and more studies are being 
conducted in this area. It is not only sufficient to know mathematics itself, but it is also important to have competent educators who can apply their knowledge and nurture mathematical thinking in the classroom [8]. To teach students meaningful mathematics in the classroom, besides having content knowledge, the teacher needs to know how to teach problem-solving effectively [9], [10].

Teachers face difficulties teaching students problem-solving when basic mathematics has not sufficiently been taught in school [11]. Mastery of the basics of mathematics is important as the subject is based on the hierarchy of concepts, so students need to learn and understand this concept before they can grasp other concepts. Failure to learn basic mathematical skills in a previous lesson may affect the future teaching and learning process and contribute to difficulties in understanding problemsolving [10]. Besides that, obstacles such as a lengthy syllabus, a packed curriculum, unfinished assessments, continuing courses, and training also hinder teachers from focusing on teaching effectively [11].

In Trends in Mathematics and Science Study (TIMSS), teachers were asked to answer a questionnaire provided by the International Association for the Evaluation of Educational Achievement (IEA). The questionnaire focused on the educational background of the teachers and principals, the views of Mathematics and Science teachers regarding working satisfaction, the teachers' teaching experience, and their involvement in professional development training. The results showed that a higher education background and job satisfaction led to better student achievement. However, these factors did not affect student achievement, as their achievement in TIMSS was still below the average score set by IEA. Moreover, in Malaysia, one of the major issues in education is the lack of problem-solving and higher-order thinking skills among students [12].

Therefore, this study aims to identify the teaching strategies that work well for teaching mathematical problem-solving in secondary school and the problems faced by teachers in teaching mathematical problem-solving.

\section{Methodology}

This study is based on a qualitative research design. Purposive sampling was used to select the informants. The selection of the informants was made based on the needs and objectives of the study. The informants included three Additional Mathematics teachers from a secondary school in the district of Kota Tinggi, Johor. The details of the informants are given in Table 1. The researchers collected views from these secondary school mathematics teachers to gain insight into their strategies in teaching students mathematical problem-solving. This information is best acquired and interpreted using qualitative data collection and analysis.

Table 1. Details of the Informants

\begin{tabular}{|l|l|c|}
\hline Informant & Education Background & $\begin{array}{c}\text { Years of } \\
\text { Teaching } \\
\text { Mathematics }\end{array}$ \\
\hline Teacher 1 & $\begin{array}{l}\text { Bachelor of Mathematics in } \\
\text { Education Minor Physics }\end{array}$ & 30 years \\
\hline Teacher 2 & $\begin{array}{l}\text { Bachelor of ICT Education } \\
\text { Minor Mathematics } \\
\text { Master in Mathematics } \\
\text { Education }\end{array}$ & 8 years \\
\hline Teacher 3 & $\begin{array}{l}\text { Bachelor of Mathematics } \\
\text { Education Minor Chemistry }\end{array}$ & 16 years \\
\hline
\end{tabular}

\subsection{Data Collection}

The data were collected using semi-structured interviews. An interview is a face-to-face interaction between the interviewer and the interviewee to get relevant information verbally. Before conducting the interview, the researchers set a date and time with the informants at their convenience. During the interview, the researcher developed a good rapport with the informants to create a comfortable and conducive environment for an informational interview. The researcher also prepared an interview protocol as a guide to ensure the interviewer would acquire the information per the research objectives. The interviews were recorded and then transcribed for subsequent analysis.

\subsection{Data Analysis}

In this research, a thematic analysis was used to analyze the interview transcripts. Thematic analysis is a method of identifying, analyzing, and reporting themes within a piece of data [13]. There are six steps to conduct an inductive thematic analysis, as shown in Table 2 below: 
Table 2. The Steps for conducting a Thematic Analysis

\begin{tabular}{|c|c|}
\hline Step & Description \\
\hline $\begin{array}{l}\text { Familiarise } \\
\text { yourself with } \\
\text { the data }\end{array}$ & $\begin{array}{l}\text { The researcher listens to the audio } \\
\text { recorder that has recorded the interview } \\
\text { a few times. Then, the information data } \\
\text { is transcribed into a written form and } \\
\text { repeated reading is done to make sure } \\
\text { the researcher truly understands the } \\
\text { transcript. }\end{array}$ \\
\hline $\begin{array}{l}\text { Generate initial } \\
\text { codes }\end{array}$ & $\begin{array}{l}\text { After familiarising with the data, the } \\
\text { researcher starts identifying the } \\
\text { preliminary codes to identify the data } \\
\text { that may seem relevant and interesting } \\
\text { to answer the research questions. }\end{array}$ \\
\hline $\begin{array}{l}\text { Searching for } \\
\text { themes }\end{array}$ & $\begin{array}{l}\text { After generating the initial codes, the } \\
\text { data is collated, and the researcher re- } \\
\text { focuses the analysis on a broader level } \\
\text { of themes. The codes become themes or } \\
\text { subthemes. }\end{array}$ \\
\hline $\begin{array}{l}\text { Reviewing the } \\
\text { themes }\end{array}$ & $\begin{array}{l}\text { At this phase, the researcher has the } \\
\text { evidence of whether or not some of the } \\
\text { themes have enough data to support } \\
\text { them, so the researcher can merge the } \\
\text { data or remove certain themes. }\end{array}$ \\
\hline $\begin{array}{l}\text { Defining and } \\
\text { naming themes }\end{array}$ & $\begin{array}{l}\text { At this point, the researcher develops a } \\
\text { detailed analysis of each theme, } \\
\text { provides a theme name, and identifies } \\
\text { whether the themes contain subthemes } \\
\text { or not. }\end{array}$ \\
\hline $\begin{array}{l}\text { Producing the } \\
\text { report }\end{array}$ & $\begin{array}{l}\text { The researcher transforms the analysis } \\
\text { into writing and makes sure the analysis } \\
\text { provides a concise, coherent, logical, } \\
\text { and non-repetitive story of the data } \\
\text { within the themes and makes sure that } \\
\text { the analysis answers the research } \\
\text { questions. }\end{array}$ \\
\hline
\end{tabular}

\section{Results}

Table 3 below shows the themes, subthemes, and codes that the researcher developed inductively from the data. The major themes developed from the analysis were teaching strategies, the problems faced by teachers, and the solutions to overcome the problems. The teaching strategies that the teachers used were categorized into three subthemes, namely Easy-Maths Model, Polya Model, and Cut-StopSolve Model. As for the problems faced by the teachers, the findings showed that the teachers faced almost similar challenges with the predominant problems being the students' poor mathematical foundation and attitude. The solutions to overcome these problems were also found from the analysis and emerged as four approaches, namely, strengthen students' mathematical foundation, attract students' interest, conduct extra classes, and use the EasyMaths Model.
Table 3. Inductive Themes, Subthemes, and Codes

\begin{tabular}{|c|c|c|}
\hline Theme & Subtheme & Code \\
\hline \multirow{7}{*}{$\begin{array}{l}\text { Teaching } \\
\text { strategies }\end{array}$} & \multirow{2}{*}{$\begin{array}{l}\text { Easy-Maths } \\
\text { model }\end{array}$} & Simplified method \\
\hline & & Mnemonic device \\
\hline & \multirow{4}{*}{ Polya Model } & Understand the problem \\
\hline & & Devise a plan \\
\hline & & Carry out a plan \\
\hline & & Look back \\
\hline & $\begin{array}{l}\text { Cut-Stop- } \\
\text { Solve Model }\end{array}$ & $\begin{array}{l}\text { Cut a little of the } \\
\text { questions' sentences }\end{array}$ \\
\hline \multirow{4}{*}{$\begin{array}{l}\text { Problems } \\
\text { faced by } \\
\text { teachers }\end{array}$} & \multirow{2}{*}{$\begin{array}{l}\text { Weak } \\
\text { mathematical } \\
\text { basis }\end{array}$} & $\begin{array}{l}\text { Weak students taking } \\
\text { Additional Mathematics }\end{array}$ \\
\hline & & Underqualified students \\
\hline & \multirow{2}{*}{$\begin{array}{l}\text { Student } \\
\text { attitude }\end{array}$} & Absenteeism \\
\hline & & Mentality of students \\
\hline \multirow{7}{*}{$\begin{array}{c}\text { Solutions } \\
\text { to } \\
\text { overcome } \\
\text { the } \\
\text { problems }\end{array}$} & $\begin{array}{l}\text { Strengthen } \\
\text { the } \\
\text { mathematical } \\
\text { basis }\end{array}$ & Train back-to-basics \\
\hline & \multirow{3}{*}{$\begin{array}{l}\text { Attract } \\
\text { student } \\
\text { interests }\end{array}$} & $\begin{array}{l}\text { Prove they can do } \\
\text { mathematical problem- } \\
\text { solving }\end{array}$ \\
\hline & & Use a storytelling method \\
\hline & & Use a sense of humour \\
\hline & $\begin{array}{l}\text { Conduct } \\
\text { extra classes }\end{array}$ & $\begin{array}{l}\text { Cover all exercises } \\
\text { regarding mathematical } \\
\text { problem-solving }\end{array}$ \\
\hline & \multirow{2}{*}{$\begin{array}{l}\text { Use Easy- } \\
\text { Maths model }\end{array}$} & Use a simplified method \\
\hline & & Use a mnemonic device \\
\hline
\end{tabular}

\section{Discussions}

\subsection{Theme 1: Teaching Strategies}

\section{Easy-Maths Model}

The Easy-Maths Model is one of the teaching strategies invented by a teacher at Sekolah Menegah Kebangsaan near Kota Tinggi, Johor. This model was invented to change the students' perception and mentality that viewed Additional Mathematics as a hard subject, instead, turning it into an interesting and fun subject. The teacher/inventor has been using the Easy-Maths Model since 1993 and claims that the percentage of school examination results had become better since.

I invented one method named 'Easy-Maths' after doing some research, and since 1993, my school's examination results have been quite good. When inventing this method, my first aim was to attract the students' attention to like learning Additional Mathematics, by making the subject fun, because the students will learn if they have fun learning the subject (Teacher 1).

To help students better understand mathematical problem-solving questions, it is important to attract the students' interest in the subject before problemsolving. When solving a mathematical problem, the Easy-Maths Model could be used to simplify 
problem-solving by breaking down the question into a few steps. This model helps the students memorize the question step-by-step.

I use the Polya Model, but if my students do not understand this method, I will use the Easy-Maths Model. I have already applied the techniques from the Easy-Maths Model in my class, and I can see how the techniques have captured my students' interest and attention (Teacher 2).

...I invented the Easy-Maths Model to focus on simplifying the method for every topic (Teacher 1).

The Easy-Maths Model simplifies the existing method to help the students memorize the solution step by step (Teacher 2).

The strategies used in the Easy-Maths Model require the students to engage their cognitive ability. There are some skills that students need to know before solving a problem. This model provides steps for solving every topic or problem in Additional Mathematics.

Easy-Maths has steps for every topic. I go through the problems by topic because every topic has its solutions and method to solve the problem. I make it into the easiest and simplest steps for the students to remember (Teacher 1 ).

The teacher uses a mnemonic device to help the students remember the steps for some topics. A mnemonic device is one of the methods that could make the students remember the method easier. It is also one of the techniques to improve memory [14]. There are many types of mnemonic devices. In this study, the researcher already discovered that the Easy Maths model used acrostics mnemonics and the acronym mnemonics. For the acronym mnemonics, the first letter in a list of words is used to create a new word - a method that has proven to be the easiest way to remember things.

In the topic of the solution for triangles, to find the area of a triangle, I used the acronym LUASSSS. In this case, 'LUAS' means, area. The first $S$ is 'setengah' (half), the second $S$ is 'sisi' (side), the third $S$ is 'sin' (sine), and the fourth $S$ is 'sudut' (Angle) (Teacher 1).

The above equation presents a formula that will help the students remember easier. The original formula is shown in Equation 1. For acrostic mnemonics, the first letter in the list of words serves as the first letter in a new sentence or phrase [14].

$$
\text { area }=\frac{1}{2} \times a \times b \times \sin c
$$

This method is possibly effective because it can attract mathematically weak students to understand and love Additional Mathematics first, before going through the problem-solving questions. Teacher 1 also agrees, stating that:
If the students have an interest in a subject, even when we give 10 questions, they will do all of them as long as they are interested (Teacher 1).

\section{Polya Model}

Most of the teachers used a Polya Model for teaching mathematical problem-solving in class because the model provides four clear steps that help students answer mathematical problem-solving questions. In this study, Teacher 2 used the Polya Model in class. This model involves 4 steps [15], namely:

\section{Understand the problem}

Teacher 2 stated that the students have to understand all the words used for stating the problem. They need to know what the questions ask them to find. They also have to know how to restate the problem in their own words before going to the next step. This is evident from Teacher 2's statement below:

In the first step, I will give a question regarding problem-solving; then, the students will sit in a group, discuss, read, and understand the question given. In the first step, the students will identify the problem (Teacher 2).

\section{Devise a plan}

There are many reasonable ways to solve the problem. When people are used to solving many problems, they will tend to choose an appropriate strategy to solve the problem, as per Teacher 2's response:

In the second step, the students extract important information from the question. For example, they convert mathematical sentences into a mathematical equation (Teacher 2).

\section{Carry out the plan}

Once the students have a suitable approach to solve a mathematical problem, they will try it out and see if it leads to a solution. If not, they will use another approach until they find the solution. Teacher 2 elaborates on Step 3 below:

In the third step, the students discuss which method is suitable to solve the problem such as the experimental method, the analysis method, the basic operational mathematics method, or the creative method to produce a timetable or diagram (Teacher 2).

\section{Look back}

The last step involves the students rechecking the steps that they have done from Step 1 until Step 4. From this model, Teacher 2 can identify the steps in which the students encountered problems. Teacher 2 further elaborates on the Polya Model as below: 
The last step involves the students rechecking the steps they have taken from Step 1 until Step 4. From this model, I can identify the steps in which the students faced problems (Teacher 2).

\section{Cut-Stop-Solve Model}

This model is a simple model invented by Teacher 3 from a secondary school near Kota Tinggi. Problem-solving usually involves long sentences, which makes it hard to identify and understand what a question wants. Therefore, this strategy helps students answer lengthy-type questions. If there is any information that is found from the question, students will stop reading it. Then, they will start to extract the information and label any diagram that exists in the question. If the initial information can be solved, they will solve it first, then, they will continue using these steps until the end of the sentences. Teacher 3 supports this strategy, stating that:

While reading a question, when the students identify the information that they can bring out from the question, I will ask them to stop reading and bring out that information. Then, they will continue with that step until the end of the question. If there is a diagram, they will label the initial information in the diagram (Teacher 3 ).

This strategy is the most effective because when using this approach, students can bring out all the information, instead of being burdened with what the questions want. Usually, when students see incomplete information from the diagram or when they read all of the questions, they will not know when to start solving the question. Teacher 3 further explains this issue:

Sometimes, the students do not know what the questions want, but when using this method, students can bring out the initial information. When I see the students start bringing out the initial information, and then start labelling the diagram, I will know that the students can analyse the questions although the questions have long sentences (Teacher 3).

\subsection{Theme 2: Problems Faced by Teachers}

\section{Weak Mathematical Basis}

The Additional Mathematics syllabus takes into consideration the content of the mathematics curriculum. In mathematics, students have to learn the hierarchy of a concept in order to learn another concept. Failure to learn basic math skills may affect the teaching and learning process. Additional Mathematics can be considered a new area of mathematics that emphasises problem-solving as part of the teaching and learning process. Therefore, if the students' basis of mathematics is weak, it will be hard for them to answer problem-solving questions.

Most of the students have a weak mathematical basis because of their weak fundamental understanding of mathematics since lower secondary school. It is important to equip the students with a good mathematical foundation because a good understanding of a mathematical concept is necessary for them to learn another concept [16]. Failure to learn or understand specific concepts can lead to difficulties in mathematics, thus, causing an inability to solve mathematical problems. Teacher 1 further explains this issue:

Weak students also take Additional Mathematics and their basis is not strong. When they are in Form 5, and their foundation is still not strong, I feel pity for teachers who have to teach them (the Form 5 students) because they will have to teach them the basics of the subject from the beginning. Moreover, most school authorities start conducting extra classes when the students are in Form 5, but by this time it is too late because their foundation is not strong (Teacher 1).

Before this, at my age, students who took pure sciences were quality students. But now, if students only passed the Mathematics subject during Pentaksiran Tingkatan 3 (PT3), they are already qualified to go to the pure science stream. Besides, most school authorities will look to guard the students' interests although the students are not qualified (Teacher 2).

At the beginning of my experience teaching Add Maths (Additional Mathematics), students at the fifth-class level would also take Add Maths. Although the students only get grades $D, E$, and mostly failed for Mathematics in Penilaian Menengah Rendah (PMR) at that time, they would still take Add Maths. When their basis is not strong, the students will think that Add Maths is hard and they will lose marks for not solving basic mathematical steps (Teacher 3 ).

\section{Student Attitude}

The student attitude towards learning also affects the teachers who teach mathematical problemsolving. Most of these students do not want to go to school. This attitude burdens teachers. Teacher 1 elaborates on this scenario in more detail:

On Sunday, the students do not come to school because of the school assembly. On Thursday, they do not come to school because it is the last day of school for that week, so, when the students do not come to school, it will be a problem. If they come to school, no matter how bad their academic performance is, I can still help them in their studies (Teacher 1). 
Besides that, previous students tend to spread rumours that Additional Mathematics is hard so the new students will be influenced. These rumours affect the students' mentality towards Additional Mathematics. Teacher 3 supports this case, stating that:

There is still a culture of accepting the rumours that Add Maths is hard, which influences students. At the beginning of introducing the subject package for Form 4 students, one of the students' questions is "Is it true that Add Maths is hard? My sister, my brother, my friends have already taken Add Maths, and they say it is hard." These rumours disturb the students' minds and affect their motivation to take Add Maths (Teacher 3).

Student failure in academic achievement may due to various reasons such as negative attitudes towards mathematics and high anxiety in learning. This attitude is built by several factors such as the level of self-confidence, peer groups, environmental pressures, teacher methods, and negative classroom experience [17]. To succeed in learning mathematics, it is necessary to determine the students' negative attitudes and positive attitudes toward mathematics.

\subsection{Theme 3: Solutions to Overcome the Problems}

\section{Strengthen Mathematical Basis}

To answer any kind of question including mathematical problem-solving or higher-order thinking skills (HOTS) items, the student's knowledge base first has to be strong. The mathematical basis or foundation is very important. Teachers need to ensure that every student has mastered basic skills in mathematics and students need to equip themselves with mathematical knowledge and skills so that it is easier to solve mathematical problems involving HOTS. Difficult situations will be faced by students who do not have clear plans and strategies for solving mathematics problems. If the students have a weak foundation, they will have a high tendency to fail to answer maths problem questions. Teacher 1 states that:

HOTS questions involve our everyday lives, so we have to relate it to real-life problems. Before answering HOTS items, we have to strengthen the foundation of the students first. It is useless to do HOTS questions if the students have a weak basis in mathematics (Teacher 1).

Therefore, the teachers also focused on teaching mathematical basics at the beginning of the week to strengthen the students' foundation. It is undeniable that most students have a weak mathematics foundation, thus, teachers can also use a variety of activities and techniques to help strengthen the connections between what students already know of the concepts and what they need to know [18]. Teacher 3 reiterates this point below:

In the first week of the teaching and learning process at the beginning of the school year, there is a back-to-basics training drill for every Form 5 student so that when they learn the basics, they will think their foundation is $\mathrm{OK}$, then, from that, they will think their Add Maths is also OK (Teacher 3).

\section{Attract Student Interest}

In the teaching and learning process, teachers should know and identify why students do not understand certain subjects. Most of the students are memorising and repeating the same strategies they learned in the classroom. This finding suggests the need for teachers to attract students' interest in learning mathematics [19]. Before going through a mathematical problem-solving question, first, the teachers should attract their students' interest in Additional Mathematics [20]. When the students already have an interest in the subject, any strategies, methods, or techniques used by the teachers will be accepted and will be easier for the students to apply [21]. Teachers could use many tools to attract student attention [22]. Some of these methods are elaborated further below:

Weak students love the storytelling method. They love humour, so I use both in my class to attract students to learn (Teacher 1).

I tackle students with acting, drama, or by giving some gifts to attract their interest (Teacher 2).

In the beginning, I give some easy questions about Add Maths to the students to prove that they can solve mathematical problems (Teacher 2).

The most important thing in learning is fun, which includes the use of humour, acting, dramas, and storytelling. Before teaching any topics or any kind of questions, teachers first have to attract the students' interest to create conducive learning environment and avoid stress for the students. Furthermore, teachers can help students to connect mathematics with real-life experience in developing students' conceptual knowledge. Students can view mathematics as something interesting and relevant if they know how to use mathematics as a tool to solve problems in their daily life [23].

\section{Do Extra Classes}

In the classroom, usually, the teachers complain that there is not enough time to complete the syllabus and they have no time to do or discuss some exercises relating to the Sijil Pelajaran Malaysia (SPM) examination. Therefore, in this study, the teachers suggested that doing extra classes could help overcome this particular problem. 
Through the extra classes, the students will be able to understand a topic more. The teachers also will not need to rush to complete the syllabus. They can train their students to solve mathematical questions so that the students will be familiar with the question patterns. This case is explained in more detail below:

I conduct an extra class for my students every Friday for Add Maths. I also increase the number of exercise questions in my class to help the students see and get used to the pattern of questions (Teacher 1).

I have an extra class for my students to finish the syllabus. From that, I increase their training drills (Teacher 3).

\section{Use Easy-Maths Model}

Besides using the Easy-Maths model as a teaching strategy, some teachers also use this model to teach mathematical problem-solving in class. Since the method is effective in helping students learn, the teachers also use the Easy-Maths model as a technique to promote and change the mentality of the students. Normally, students who have a problem learning mathematics will have mathematics phobia. These students could be very good at mathematics but their prior knowledge of the subject is very poor so the teacher should be concerned and help guide the student to enhance his or her confidence in solving mathematical problems [24]. Teacher 2 explains this case in more detail:

I use Easy Maths methods invented by the Guru Cemerlang at this school and I already include these methods in my class. From there, I can see the effectiveness of Easy Maths in attracting student interest (Teacher 2).

The Easy-Maths model involves a simplified method and the use of a mnemonic device. Students love simple methods especially when the methods lead them to answer the questions. Besides, a mnemonic device helps students improve their memory in the long run. This device is included in every topic in the Easy-Maths method.

\section{Conclusions}

Generally, this study aimed to explore the strategies that teachers used to teach mathematical problem-solving. It also elaborated on the problems faced by the teachers and the solutions to overcoming these problems. The main focus was on the
Additional Mathematics subject. From the findings, various teaching strategies could be used as long as they suit the student learning style. In this study, the Polya Model, the Easy-Maths Model, and the CutStop-Solve Models were the teaching strategies used by the informants to teach mathematical problemsolving at school. Plus, from the responses presented in the findings, all these strategies have been proven effective.

However, the teachers still face some problems in teaching mathematical problem-solving such as the students' weak mathematical basis and bad attitude towards learning. It is undeniable that although the teachers have made a great effort to attract student interest to the subject, it is still hard to gauge the ability or skill of every student in problem-solving. Therefore, the teachers could strengthen the student's basis first, and then attract their interest to learn, and lastly conduct extra classes to increase their knowledge and understanding of every Additional Mathematics concept and skill.

It can be concluded that the teachers in the selected school have unique strategies for helping students learn mathematical problem-solving. It may take time to see the effectiveness of the methods used, but as long as the teachers know their students well, treat them accordingly, and know the students' learning styles, so it could be easier for the students to answer mathematical problem-solving using the best teaching strategy that suits them.

\section{Recommendations}

This study explores teaching strategies for mathematical problem-solving through the lens of secondary school teachers in the area of Kota Tinggi. It only covers the perspective of teachers of one school in the area of Kota Tinggi with limited informants. Therefore, the future study can increase the informants and the number of schools to be chosen for better conformability and credibility of the findings. The future study can also vary the sample for not only involving secondary schools' teachers, but also preschools' teachers, primary schools' teachers, and university lecturers.

This study used general qualitative inquiry as its qualitative research strategy to collect and interpret data acquired. Future research could have better insights into the phenomenon being studied by applying other qualitative research studies for viewing the phenomenon from different perspectives such as phenomenology, ethnography, action research, or case study. 


\section{References}

[1]. Liljedahl, P., Santos-Trigo, M., Malaspina, U., \& Bruder, R. (2016). Problem Solving in Mathematics Education. In Problem Solving in Mathematics Education (pp. 1-39). Springer, Cham. https://doi.org/10.1007/978-3-319-40730-2_1

[2]. Kurniati, D., Purwanto, As'ari, A. R., \& Dwiyana. (2018). Exploring the mental structure and mechanism: How the style of truth-seekers in mathematical problem-solving?. Journal on Mathematics Education, 9(2), 311-326. https://doi.org/10.22342/jme.9.2.5377.311-326

[3]. Son, A. L., Darhim, \& Fatimah, S. (2020). Students' mathematical problem-solving ability based on teaching models intervention and cognitive style. Journal on Mathematics Education, 11(2), 209-222. https://doi.org/10.22342/jme.11.2.10744.209-222

[4]. Siniguian, M. T. (2017). Students difficulty in solving mathematical problems. International Journal of Advanced Research in Engineering and Applied Sciences, 6(2), 1-12.

[5]. Tambychik, T., \& Meerah, T. S. M. (2010). Students' difficulties in mathematics problem-solving: What do they say?.Procedia-Social and Behavioral Sciences, 8, 142-151.

https://doi.org/https://doi.org/10.1016/j.sbspro.2010.1 $\underline{2.020}$

[6]. Ramsden, P. (2003). Learning to teach in higher education. Routledge.

[7]. Jalbani, L. N. (2014). The Impact of Effective Teaching Strategies on the Students' Academic Performance and Learning Outcome. Munich: GRIN Verlag

[8]. Koçak, Z. F., Bozan, R., \& Işık, Ö. (2009). The importance of group work in mathematics. ProcediaSocial and Behavioral Sciences, 1(1), 2363-2365. https://doi.org/https://doi.org/10.1016/j.sbspro.2009.0 $\underline{1.414}$

[9]. Chapman, O. (2015). Mathematics teachers' knowledge for teaching problem solving. LUMAT: International Journal on Math, Science and Technology Education, 3(1), 19-36. https://doi.org/10.31129/lumat.v3i1.1049

[10]. Ling, C. Y., Osman, S., Daud, M. F., \& Hussin, W. N. W. (2019). Application of Vee Diagram as a problem-solving strategy in developing students' conceptual a nd procedural knowledge. International Journal of Innovative Technology and Exploring Engineering (IJITEE), 8(10), 2796-2800. https://doi.org/10.35940/ijitee.J9591.0881019

[11]. Pearce, D. L., Bruun, F., Skinner, K., \& LopezMohler, C. (2013). What teachers say about student difficulties solving mathematical word problems in grades 2-5. International Electronic Journal of Mathematics Education, 8(1), 3-19.
[12]. Zaharin, N. L., Sharif, S., \& Mariappan, M. (2018). Computational Thinking: A Strategy for Developing Problem Solving Skills and Higher Order Thinking Skills (HOTS). Int. J. Acad. Res. Bus. Soc. Sci, 8(10). https://doi.org/10.6007/IJARBSS/v8-i10/5297

[13]. Braun, V., \& Clarke, V. (2006). Using thematic analysis in psychology. Qualitative research in psychology, 3(2), 77-101. https://doi.org/10.1191/1478088706qp063oa

[14]. Putnam, A. (2015). Mnemonics in Education: Current Research and Applications. Translational Issues in Psychological Science, 1(2), 130-139. https://doi.org/10.1037/tps0000023

[15]. Pólya, G., \& Conway, J. H. (1957). How to solve it: A new aspect of mathematical method. Princeton, NJ: Princeton University Press.

[16]. Özreçberoğlu, N., \& Çağanağa, Ç. K. (2018). Making it count: Strategies for improving problemsolving skills in mathematics for students and teachers' classroom management. Eurasia Journal of Mathematics, Science and Technology Education, 14(4), 1253-1261. https://doi.org/10.29333/ejmste/82536

[17]. Yaratan, H., \& Kasapoğlu, L. (2012). Eighth grade students' attitude, anxiety, and achievement pertaining to mathematics lessons. Procedia-Social and Behavioral Sciences, 46, 162-171. https://doi.org/10.1016/j.sbspro.2012.05.087

[18]. McLaren, D. (2010). Does Theory Have Any Poínt?. Mathematics in School, 39(5), 2-9.

[19]. Gafoor, K. A., \& Kurukkan, A. (2015). Learner and Teacher perception on Difficulties in Learning and Teaching Mathematics: Some Implications. National Conference on Mathematics Teaching-Approaches and Challenges, 232-242.

[20]. Hill, H. C., \& Ball, D. L. (2004). Learning mathematics for teaching: Results from California's mathematics professional development institutes. Journal for research in mathematics education, 35(5), 330-351. https://doi.org/10.2307/30034819

[21]. Gurat, M. G. (2018). Mathematical Problem-Solving Strategies among Student Teachers. Journal on Efficiency and Responsibility in Education and Science, 11(3), 53-64. https://doi.org/10.7160/eriesj.2018.110302

[22]. Çelik, A. Ö., \& Güzel, E. B. (2017). Mathematics Teachers' Knowledge of Student Thinking and Its Evidences in Their Instruction. Journal on Mathematics Education, 8(2), 199-210.

[23]. Anthony, G., \& Walshaw, M. (2009). Characteristics of effective teaching of mathematics: A view from the West. Journal of Mathematics Education, 2(2), 147164.

[24]. Ramli, F., Shafie, N., \& Tarmizi, R. A. (2013). Exploring student's in-depth learning difficulties in mathematics through teachers' perspective. ProcediaSocial and Behavioral Sciences, 97, 339-345. https://doi.org/10.1016/j.sbspro.2013.10.243 